\title{
Retrospective donor hepatectomy results in living donor liver transplant- A single-center experience
}

\author{
Canlı vericili karaciğer naklinde retrospektif donör hepatektomi sonuçları- Tek merkez \\ deneyimi
}

\section{Ramazan Dönmez ${ }^{1}$, Oya Andaçoğlu ${ }^{2}$}

\begin{abstract}
Objectives: We aimed to describe our technique and donor selection for donor hepatectomy, review our case series and report our complication rates and outcomes.

Materials and Methods: We retrospectively reviewed 41 consecutive donor hepatectomy cases between October 2019 and November 2020 at Yeditepe University, Istanbul, Turkey. Complications were graded according to Clavien-Dindo classification. All cases were performed via laparotomy.

Results: Out of 41 donor cases, 38 (92.6\%) were right lobe, 2 (4.8\%) were left lobe and 1 (2.4\%) was left lateral segment donor hepatectomy. Follow up was $9 \pm 2,2$ months (4-16 months). There were 8 (19.5\%) complications and all were minor (grade 1 or 2). There were no grade 3 or higher complications. Three (7.3\%) of our donors are heterozygous for Factor Leiden mutation and 4 (9.7\%) of our donors had heterozygous prothrombin mutation. Length of stay was average $6.4 \pm 1.4$ days (range $=5-12$ ). Ten donors lost weight with a supervised diet and exercise program. There was one wound complication in this subset of patients.

Conclusions: We present our single center donor hepatectomy series with excellent results. We also describe successful weight loss for donors with Body Mass Index $>30 \mathrm{~kg} / \mathrm{m}^{2}$. Donor safety is the most important component of living donor liver transplantation. As donor results continue to improve, living donor liver transplant will continue expand worldwide.
\end{abstract}

Keywords: Donor complication, donor hepatectomy, liver transplantation, weight loss

Öz

Amaç: Donör hepatektomi tekniğimizi ve donör seçimimizi tanımlamayı, vaka serimizi gözden geçirmeyi, komplikasyon oranlarımızı ve sonuçlarımızı bildirmeyi amaçladık.

Gereç ve Yöntemler: Yeditepe Üniversite Hastanesi'nde Ekim 2019- Kasım 2020 tarihleri arasında 41 ardışık donör hepatektomi olgusunu retrospektif olarak inceledik. Komplikasyonlar Clavien-Dindo sınıflamasına göre derecelendirildi. Tüm olgular laparotomi ile yapıldı.

Bulgular: 41 donör olgusunun 38'i $(\% 92,6)$ sağ lob, 2'si $(\% 4,8)$ sol lob ve 1'i $(\% 2,4)$ sol lateral segment donör hepatektomisi idi. Takip süresi $9 \pm 2,2$ aydı (4-16 ay). Sekiz $(\% 19,5)$ komplikasyon vardı ve hepsi minördü (derece 1 veya 2). Derece 3 veya daha yüksek komplikasyon görülmedi. Üç donörde heterozigot Faktör 5 Leiden

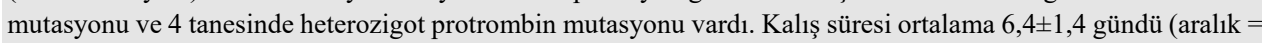
5-12). Kontrollü diyet ve egzersiz programı ile 10 donör kilo verdi. Bu hasta alt grubunda bir yara komplikasyonu vard1.

Sonuç: Tek merkezli donör hepatektomi serimizi çok iyi sonuçlarla sunuyoruz. Ayrıca Vücut Kitle İndeksi $>30$ $\mathrm{kg} / \mathrm{m}^{2}$ olan donörler için başarılı kilo vermeyi de tanımlıyoruz. Donör güvenliği, canlı donör karaciğer naklinin en önemli bileşenidir. Donör sonuçları iyi oldukça, canlı vericili karaciğer nakli dünya çapında yaygınlaşmaya devam edecektir.

Anahtar Kelimeler: Donör hepatektomi, donör komplikasyonu, karaciğer nakli, kilo kaybı
${ }^{1}$ Fenerbahce University, Vocational School of Health Services, Istanbul, Turkey.

${ }^{2}$ Akdeniz University, Organ Transplantation Research and Application Center, Antalya, Turkey.

RD: 0000-0003-2455-6380

OA: 0000-0001-5777-0266

Ethics Committee Approval: This study was approved by Yeditepe University Clinical Research Ethics Committee with an approval number of 18.02.2021, 1393.

Etik Kurul Onayı: Bu çalışma Yeditepe Üniversitesi Klinik Araştırmalar Etik Kurulu tarafindan 18.02.2021, 1393 onay numarası ile onaylanmıștır.

Conflict of Interest: No conflict of interest was declared by the authors.

Çıkar Çatışması: Yazarlar çıkar çatışması bildirmemiştir.

Financial Disclosure: The authors declared that this study has received no financial support. Finansal Destek: Yazarlar bu çalışma için finansal destek almadıklarını beyan etmişlerdir.

Geliş Tarihi / Received: 30.04.2021

Kabul Tarihi / Accepted: 13.06.2021

Yayın Tarihi / Published: 02.08.2021

Sorumlu yazar / Corresponding author:

Ramazan Dönmez

Adres/Address: Atatürk Mah. Atașehir Bulvarı, Metropol İstanbul, 34758, Ataşehir - İstanbul, Turkey.

E-mail: donmez3570@gmail.com Tel/Phone: +90 2169101907

\section{Copyright $\odot$ ACEM}




\section{Introduction}

First living donor liver transplant (LDLT) in Turkey was performed by Dr. Haberal and his team in 1990. As of 2020, there are 48 liver transplant centers in Turkey according to the Ministry of Health web page [1]. Although not a part of the publicly available report, approximately 15-20 of these centers perform LDLT at least 10 or more cases annually. Donor outcomes mainly based on single center studies. Common complications after donor hepatectomy are wound infection, bile leak, and incisional hernia. According to a recent meta-analysis by Brown at al. they reported that any complication rate could up to $60 \%$ including the minor ones after donor hepatectomy [2].

Herein, we report our own center experience with donor hepatectomy, including weight loss for the potential donor, our technique, complication rates and outcomes.

\section{Material and Methods}

We retrospectively reviewed all of our donor hepatectomy medical records between October 2019 and November 2020. It is allowed up to 4 th degree relatives to donate an organ to the recipient in Turkey. We had ethics committee approval for all donor candidates if the donor was unrelated to the recipients. Institutional Review Board (IRB) permission was obtained (KAEK\#1393) for this study. Statistical analyzes were performed using SPSS v22.0 (IBM, Armonk, NY, USA). Quantitative variables were expressed as mean $\pm \mathrm{SD}$, median, min-max, and range. Qualitative variables were reported as numbers and percentages (\%). Mean and standard deviations are used for homogeneous distributions, while median and range values are given for heterogeneous distributions.

\section{Preoperative preparation of the donor}

Comprehensive laboratory tests are performed for the donor candidate including complete blood count, full chemistry, $\mathrm{C}$-reactive protein, coagulation mutations and routine coagulation labs, urinary analysis, viral serology and lipid panel. Triphasic computed tomography (CT) was obtained for the vascular anatomy and liver steatosis was determined via Hounsfield unit (HU) difference between liver and spleen and absolute HU values of the liver on non-contrast phase. If the liver average $\mathrm{HU}$ was $\geq 50$ $\mathrm{HU}$ in addition to $\mathrm{HU}$ difference Liver-spleen was $\geq 5$, it was deemed that there was no significant steatosis. In addition, ratio of liver/spleen HU> 1.1 was also considered as no significant steatosis. None of the donors had liver biopsy. Magnetic resonance cholangiopancreatography (MRCP) was performed in order to delineate the biliary anatomy. We utilized graft to the recipients' weight ratio (GRWR) and used $\geq 0.8$ cut off in addition to future liver remnant (FLR) volume of minimum $30 \%$. If liver/spleen HU ratio was $<1.1$ and/or absolute liver HU average was $<50$, this was determined as significant steatosis. Donors with $\mathrm{BMI}>30$ or donors with significant steatosis on CT scan as described above, were counseled to our dedicated nutritionist and were provided a specific diet and encouraged to lose weight before donation if there were no alternative donors. Liver cutting area and volume calculations were made in Myrian XP-Liver program. The measurements were made together by a ten-year experienced radiologist and donor surgeon. Weight loss program included the following: Uptempo walk at least twice daily, for 45 minutes minimum, black coffee twice daily, metformin $850 \mathrm{mg}$ daily, lean protein rich and low fat and low carbohydrates diet (tailored based on the needs of the individual donor by the dietician). These donors had a repeat CT scan in order to ensure weight loss and to quantify the decease in steatosis. All donors and recipients underwent an evaluation process through a multi disciplinary discussion conference which included gastroenterology, anesthesia, transplant surgery and psychiatry.

\section{Donor Hepatectomy Operation}

All donor operations were performed by a dedicated donor surgeon (RD). The donor surgeon who performed the operations had an experience of 10 years and approximately 1000 cases. All cases were open. All recipients had central venous catheter, nasogastric catheter, Foley catheter and ampicillin prophylaxis. Central venous pressure was targeted for $0-2 \mathrm{mmHg}$. Thompson automatic retractor was used in operations. Patient was on $30^{\circ}$ reverse Trendelenburg position. J-Shaped incision was used to enter the abdomen. Triangular ligaments were released. Short hepatic veins were ligated. After encircling hepatic vein, liver hanging maneuver was performed and attention was turned to the porta hepatis. After identifying the hepatic artery and portal vein, demarcation line was obtained by gentle clamping of the inflow with bulldog clamps (Figure 1). Intended resection point of the bile duct was marked with clips and routine intraoperative cholangiogram was performed through cystic duct (Figure 2).

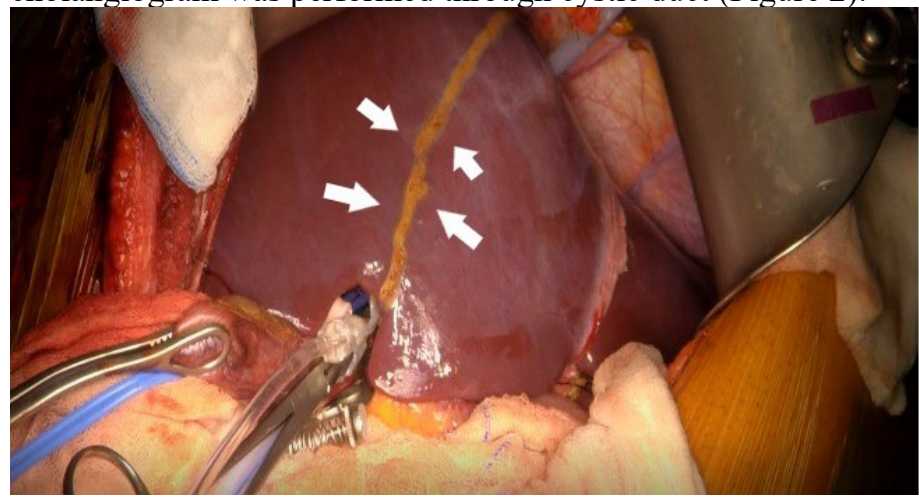

Figure 1. Demarked liver, liver hanging maneuver



Figure 2. Intraoperative cholangiogram

Parenchyma resection was performed using Cavitron ultrasonographic aspirator (CUSA, Excel 2016-01 Version) (Figure 3-4).

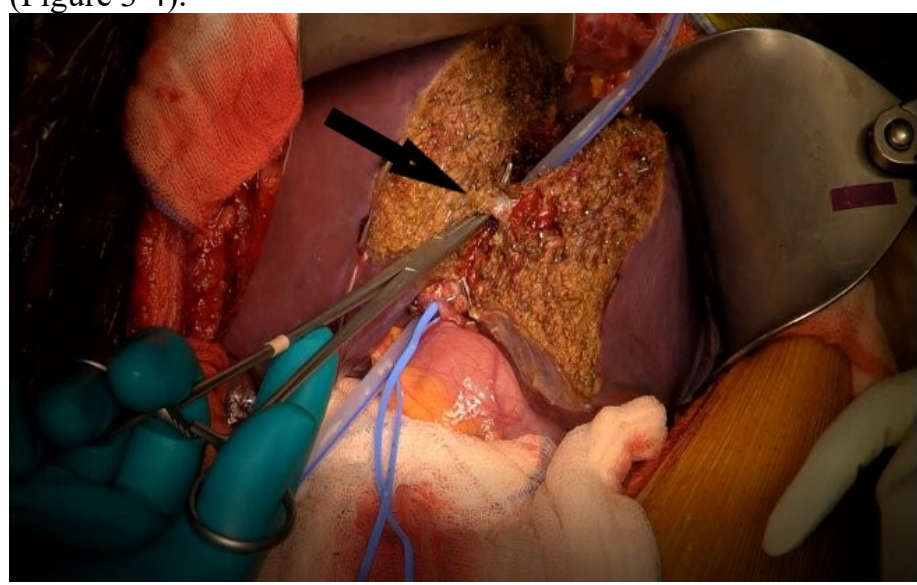

Figure 3. Paranchymal resection and Segment V vein. 


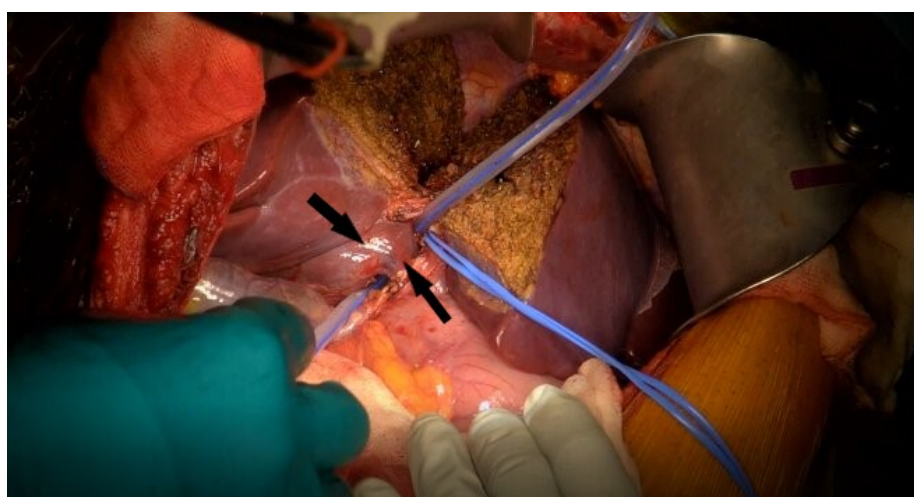

Figure 4. Paranchymal resection of the caudate lobe.

We also utilized bipolar cautery and metal clips. Middle hepatic vein was preserved for all right lobe donors. Segment V and VIII veins were re-constructed if they were $\geq 5 \mathrm{~mm}$. Extra caution was exercised to divide the biliary plate in order avoid too much dissection and to avoid ischemia of both the remnant and the graft bile duct. The bile ducts, hepatic artery, and right portal vein were cut, respectively, and dissection was completed (Figure 5-8).

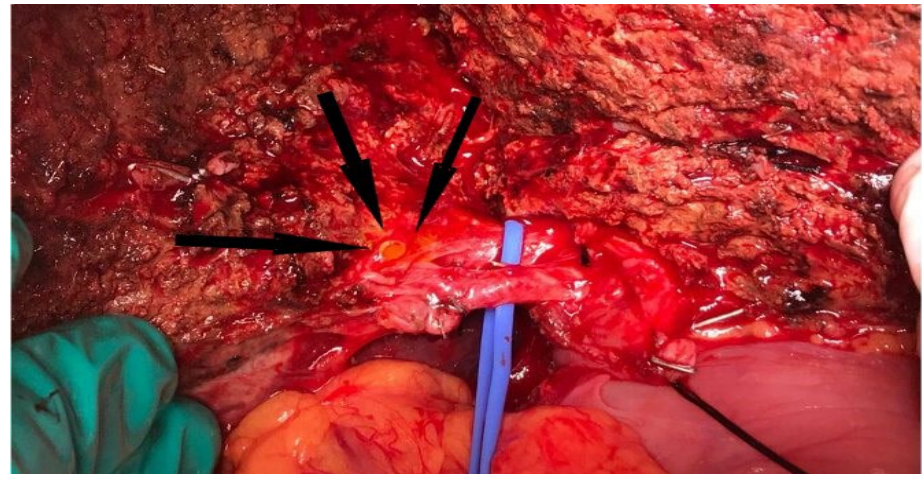

Figure 5. Transected bile duct.

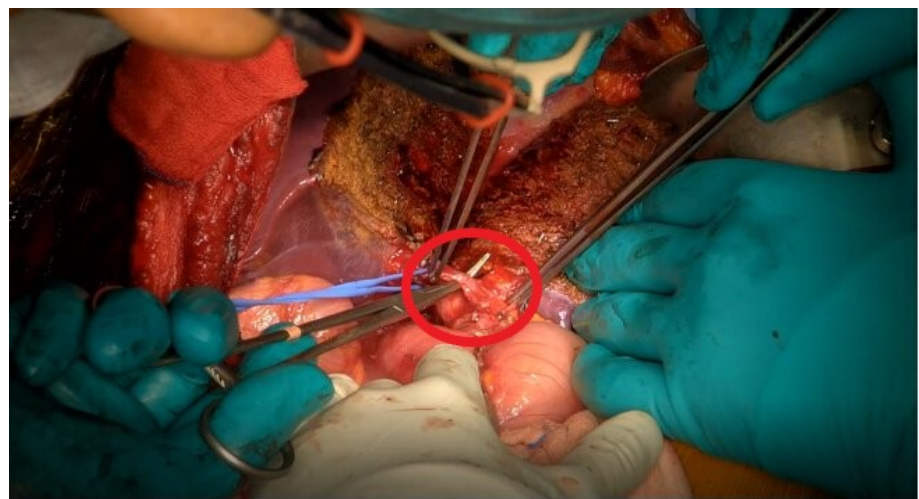

Figure 6. The right hepatic artery.

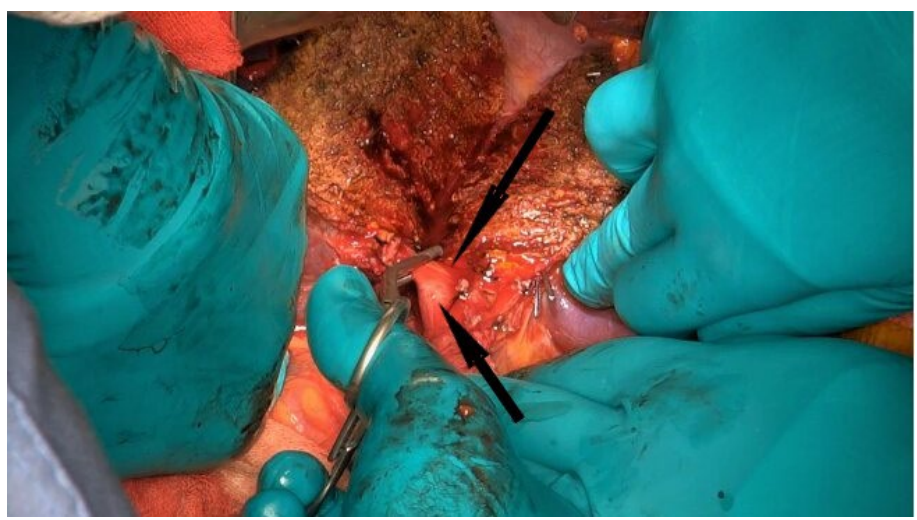

Figure 7. Clamped right portal vein.

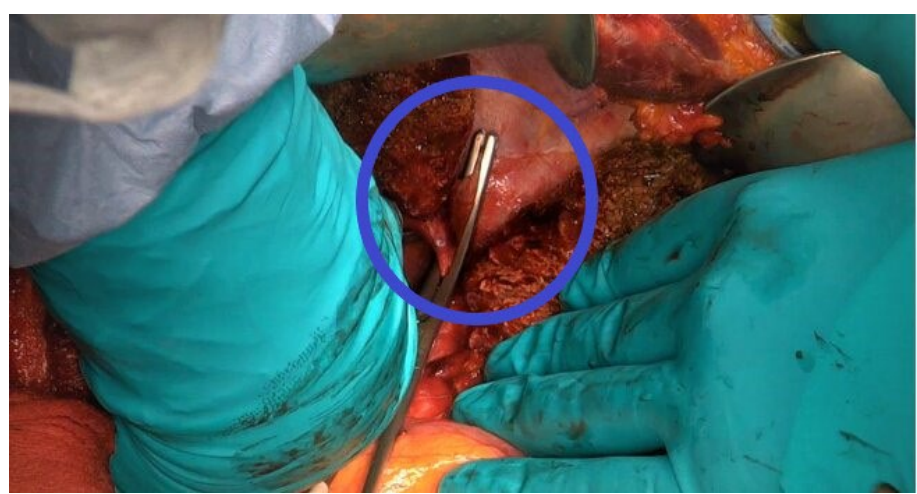

Figure 8. Clamped right hepatic vein.

In left and left lateral donor hepatectomies, the left triangular ligament was released from the top and bottom to the level of the vena cava. Parenchyma transection was performed over the line drawn from the left hepatic vein to the portal bifurcation, leaving the liver $0.5 \mathrm{~cm}$ to the right of the falciform ligament in the left lateral segmentectomy. Once graft was removed, hepatic vein stump was sutured with 4-0 prolene, portal vein and hepatic artery stumps were sutured with $6-0$ prolene, and bile duct openings were sutured with 6-0 PDS. Remnant left lobe was fixed to the abdominal wall by suturing falciform ligament to the abdominal wall after right hepatectomy cases. One silastic drain was left in the surgical site for all cases (Figure 9). Facia was closed in single layer with 1-0 PDS. Skin was closed with absorbable sutures. We utilized N-acetyl cysteine (NAC) IV infusion intra-operatively for all cases. We also utilized 1000 units IV heparin before hepatic artery division. All patients were extubated at the end of the operation, and they were observed in the intensive care unit for the initial 24 hours.

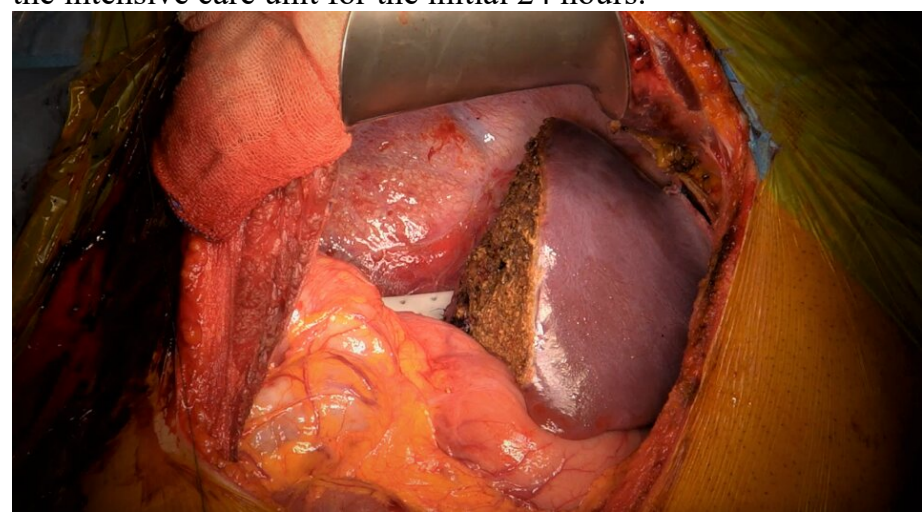

Figure 9. Remnant liver image.

\section{Post-operative Care}

All patients remained in the intensive care unit for the initial 24 hours with laboratory tests and routine Doppler ultrasound was performed on post-operative day 1 . They were moved to the regular floor on postoperative day one. Early mobilization was encouraged. Incentives spirometer was used vigorously on a daily basis. Routine antibiotics were continued for 24 hours and was continued if wound infection was suspected. We continued the parenteral NAC for 5 days. Once INR was below 1.8 , low molecular weight heparin was initiated as a prophylaxis. All the donors continued prophylactic anticoagulants for two weeks after discharge and for a month if they had any prothrombotic mutations such as factor five Leiden or prothrombin gene mutation at preoperative work up. Heterozygous Factor V Leiden mutation or Prothrombin gene mutation are not an exclusion criteria from donation at our center. Drain was removed on post-operative day 6 or 7 or when the output was less than $100 \mathrm{~mL} /$ day and serous. 


\section{Results}

Demographic features are summarized in table 1.

Table 1. Baseline characteristics of donors.

\begin{tabular}{lcc} 
Features & $\mathrm{n}$ & range or $\%$ \\
\hline Age & $33 \pm 8.1$ & $20-47$ \\
Gender Male/female & $32 / 9$ & \\
BMI & $25.14 \pm 3.9$ & $17.4-33.9$ \\
FLR & $36.18 \pm 5.7$ & $30-46$ \\
Blood loss (mL) & $108 \pm 33$ & $100-300$ \\
RL & 38 & 92.68 \\
LL & 2 & 4.8 \\
LLS & 1 & 2.4 \\
Operative time (min) & $4.4 \pm 0.5$ & $3.3-6.3$ \\
LOS (days) & $6.4 \pm 1.4$ & $5-12$ \\
Weight loss donor & 10 & 24.4 \\
Factor V Leiden & & \\
mutation(Heterozygous) & 3 & 7.3 \\
Prothrombin gene & & \\
mutation(Heterozygous) & 4 & 9.7 \\
Follow up (mo) & $9 \pm 2.2$ & $3-16$ \\
\hline
\end{tabular}

BMI: Body mass index. FLR: Future liver remnant. RL: Right lobe, LL: Left lobe, LLS: Left lateral segment, LOS: Length of stay.

We had total of 41 donor hepatectomy cases Our average age was 33, with a mean BMI of 25 . We had 10 donors with BMI above 30 or steatosis greater than $30 \%$ on CT scan who underweight weight loss and exercise program under supervision. Follow up time was 9 months. Blood loss was minimal ( $108 \pm 33 \mathrm{~mL}$, range $=100-300)$. There was no blood transfusion. Mean length of stay was 6.4 days (5-12 days). There were no re-operations due to complications. We did have total of 8 donors with complications (19.5\%) and all were minor (grade 1 or 2). There were no grade 3 or higher complications (Table 2).

Table 2. Complications of the donors.

\begin{tabular}{|c|c|c|c|}
\hline Complications & $\mathrm{n}$ & Grade & Management \\
\hline Wound infection & 3 & 2 & Prolonged antibiotic \\
\hline Prolonged dyspepsia & 2 & 1 & $\begin{array}{l}\text { Symptomatic treatment } \\
\text { Diuretics, albumin, }\end{array}$ \\
\hline Ascit & 2 & 2 & prolonged surgical drain \\
\hline Bile leak & 1 & 2 & Prolonged surgical drain \\
\hline
\end{tabular}

Two donors had prolonged dyspepsia, nausea and vomiting, requiring prolonged parenteral anti-emetics and proton pump inhibitors. Wound complications were treated with prolonged perioperative antibiotics. None of the wounds were opened. There was one bile leak that was managed by keeping the surgical drain for total of 8 weeks. Surgical drain was removed once the output was less than $50 \mathrm{~mL} /$ week. Repeat ultrasound at 10 weeks showed no collection. Ascites was defined as greater than $1000 \mathrm{~mL} /$ day serous output. Albumin and diuretics were used for these patients. We also had 10 donors who lost weight before they were accepted as liver donor. Median BMI before weight loss was 33.2 (range=28.4-37, $\mathrm{SD}=2.48$ ) and median $\mathrm{BMI}$ at operation was 29.7 (range=25.7$33.4, \mathrm{SD}=2.29)$. Three $(7.3 \%)$ of our donors are heterozygous for Factor 5 Leiden mutation and 4 (9.7\%) of our donors had heterozygous prothrombin mutation. Median LOS was 6 days for the weight loss donors. One weight loss donor had wound seroma, others had no complication. Regarding the recipients who received liver from the donors after the weight loss program, there was one bile leak and one rejection.

\section{Discussion}

The safety of the donor is the most important aspect of any living donor transplant. As this safety becomes the norm, living donor liver transplant rates would continue to increase worldwide. Therefore safe surgical techniques remain the key of successful outcomes. Herein we describe our safe technique with excellent donor outcomes.

Majority of the literature states that surgeon and center experience is closely related with lower complication rates [2-5]. Kim et al. reported that the experience of the center was important in order to decrease the complications rates of donor hepatectomy with their series of over 500 donors [3]. They divided patients into 3 periods: period A $(n=100)$, period $B(n=200)$, and period $C(n$ $=200$ ). They found that over time, the operative time, the amount of transfusions during surgery, hospital stay, and the incidence of biliary complications decreased. There was no mortality. Even though the total complication rate was high $(21.6 \%, \mathrm{n}=108)$ including $10.6 \%(n=53)$ of biliary complications, the grade 3 complication rate was $9.4 \%(n=47)$. In most patients with grade 3 complication, interventional therapies via radiologic or endoscopic approaches corrected these complications, and reoperation was required for ten patients $(2 \%)$. They also reported that biliary complications were related with operation period and operative time. They concluded that optimization of donor selection as well as institutional experience is imperative to improve the surgical outcome [3]. Even though donor hepatectomy was associated with relatively higher complication rate, most complications showed low-grade severity which could be corrected by interventional therapies. Shaji Matthew et al. reported 1 mortality due to biliary sepsis [6]. There are other series reporting biliary and overall complications after donor hepatectomy [2-10]. A recent systematic review by Braun et al. they reviewed 33 studies, reporting outcomes from 12,653 donors (right lobe: 8231, left lobe: 4422) [2]. Of 33 studies, 12 reported outcomes from right lobe donors, 1 from left lobe donors, 14 compared left and right, and 6 focused specifically on biliary complications. A total of 830 biliary complications $(6.6 \%)$ were reported, with 75 donors requiring re-operation for biliary complications and 1 donor death attributed to biliary complications [2]. They concluded that although bile leaks and strictures are still relatively common following living donor hepatectomy, the majority of complications are minor and resolve with conservative measures. Approximately $6 \%$ of living donors will experience a biliary complication and, of these $6 \%$, approximately $9 \%$ (total of $0.6 \%$ of donors) will require operative management of the biliary complication [2]. In our series, overall complication rate was $19.5 \%$ and these were all minor complications. There was one bile leak case and this resolved without the need of any intervention. However due to out small sample size, we were not able to make any comparison.

Erdogan et al. reported complications after 1521 donor hepatectomy between June 2010 and January 2018, (1291 right lobe grafts, 230 left lobe grafts) of patients who underwent LDLT [7]. Of these, 63 donors underwent endoscopic retrograde cholangiography (ERC) due to biliary complication. Biliary stricture was found in $1.6 \%(25 / 1521)$, biliary leakage in $2.1 \%$ $(33 / 1521)$, and stricture and leakage together in $0.3 \%(5 / 1521)$ donors. Their endoscopic success rates in patients with biliary leakage, biliary stricture, and stricture and leakage were $85 \%$ $(28 / 33), 92 \%(23 / 25)$, and $80 \%(4 / 5)$, respectively. Surgical treatment was performed on $12.6 \%(8 / 63)$ donors who failed ERC. They concluded that ERC is a successful treatment for post-LDLT donors who have biliary complications [7].

There also some reports reporting higher complication rates based on graft type (higher complication rates for right lobe 
donors as opposed to left lobe), however there are contradicting reports as well. [2,8-10]. In our series none of the left lobe donors had complications however we cannot make any conclusions regarding graft type and complication due to our small sample size.

Future remnant liver (FLR) is also evaluated as a risk factor for complications of the donors. Hsu et al. reported that when the future of remnant liver volume was less than $35 \%$ there was higher rate of complications. Also post operative AST, ALT, bilirubin, length of intensive care and stay and length of overall hospital stay was higher [11]. In our series among the donors with any complication, only 1 donor had less than $35 \%$ future remnant liver, all others had greater than 35\% FLR.

Lastly, there are other reports about weight loss for steatosis for living liver donors [12-16]. While most of these focus on steatosis for the potential graft, most of our cohort had high BMI in addition to the steatosis. We also report a safe and supervised weight loss program approach so that the donor pool could be further expanded. This is in concordance with the literature.

In the literature, it is reported that donors with deficiencies in Factor $\mathrm{V}$ Leiden, prothrombin mutation and anticoagulant proteins (protein $\mathrm{C}$, protein $\mathrm{S}$ and antithrombin) or coagulation factors should be rejected $[17,18]$. We also excluded donors who are homozygous. Heterozygous Factor V Leiden mutation or Prothrombin gene mutation is not a donor exclusion criterion at our center. We did not observe any complications in these donors.

The effect of standardized donor hepatectomy technique and surgical experience on the results has been demonstrated in studies in the literature $[19,20]$.

Weaknesses of our report includes the very limited sample size, short follow up, and the inability to perform statistical analysis due to aforementioned issue.

Standardization of the technique of the donor hepatectomy is the key to minimize complications. We also believe separate donor and recipient surgeons help to minimize complications. Most complications after donor surgery could be dealt with minimal invasive interventions. We also describe safe weight loss program for donors with BMI greater than 30 or donors with steatosis. These donors can donate liver safely if they comply with a strict exercise and diet program. It should be always kept in mind that donors are completely healthy individuals and the priority should always be the minimization of the donor complications.

\section{References}

1. Organ Decision Support System, Ministry of Health, Organ Transplant $\quad$ Centers. $\quad$ KY $\quad$ Software. https://organkds.saglik.gov.tr/dss/PUBLIC/ONM_LiverTransplant Center.aspx Updated December, 2019. Accesed February 6, 2021.

2. Braun HJ, Ascher NL, Roll GR, Roberts JP. Biliary complications following living donor hepatectomy. Transplant Rev (Orlando). 2016;30:247-52.

3. Kim SJ, Na GH, Choi HJ, Yoo YK, Kim DG. Surgical outcome of right liver donors in living donor liver transplantation: single-center experience with 500 cases. J Gastrointest Surg. 2012;16:1160-70.

4. Onur A, Akbulut S, Dirican A, Isik B, Yilmaz S. Life-threatening or nearly life-threatening complications in living liver donors. Clin Transplant. 2018;32:e13262.

5. Yankol Y, Mecit N, Kanmaz T, Kalayoğlu M, Acarlı K. Complications and outcomes of 890 living liver donor hepatectomies at a single center: risks of saving loved one's life. Turk J Surg. 2020;36:192-201.

6. Shaji Mathew J, Manikandan K, Santosh Kumar KY, Binoj ST, Balakrishnan D, Gopalakrishnan U, et al. Biliary complications among live donors following live donor liver transplantation. Surgeon. 2018;16:214-19.

7. Erdoğan MA, Çăğı YF, Atayan Y, Bilgiç Y, Yıldırım O, Çalışkan $\mathrm{AR}$, et al. Endoscopic treatment of biliary complications in donors after living donor liver transplantation in a high volume transplant center. Turk J Gastroenterol. 2020;31:614-19.

8. Takagi K, Umeda Y, Yoshida R, Watanabe N, Kuise T, Yoshida K, et al. Short-term and long-term outcomes in living donors for liver transplantation: Cohort study. Int J Surg. 2020;84:147-53.

9. Huang V, Chen CL, Lin YH, Lin TS, Lin CC, Wang SH, et al. Bilateral proficiency over time leads to reduced donor morbidity in living donor hepatectomy. Hepatobiliary Surg Nutr. 2019;8:459-69.

10. Goja S, Yadav SK, Saigal S, Soin AS. Right lobe donor hepatectomy: is it safe? A retrospective study. Transpl Int. 2018;31:600-9.

11. Hsu HW, Tsang LL, Ou HY, Huang TL, Chen TY, Yu CY, et al Donor Outcomes After Liver Donation in Adult to Adult Living Donor Liver Transplantation. Transplant Proc. 2018;50:2588-92.

12. Chung JH, Ryu JH, Yang KH, Choi BH, Park Y, Lee TB, et al. Efficacy and Safety of Weight Reduction of the Donor in Hepatic Steatosis for Living Donor Liver Transplantation. Ann Transplant. 2020;25:e923211.

13. Moss J, Lapointe-Rudow D, Renz JF, Kinkhabwala M, Dove LM, Gaglio PJ, et al. Select utilization of obese donors in living donor liver transplantation: implications for the donor pool. Am J Transplant. 2005;5:2974-81.

14. Oshita A, Tashiro H, Amano H, Kobayashi T, Onoe T, Ide K, et al. Safety and feasibility of diet-treated donors with steatotic livers at the initial consultation for living-donor liver transplantation. Transplantation. 2012;93:1024-30.

15. Jin YJ, Kim KM, Hwang S, Lee SG, Ha TY, Song GW, et al. Exercise and diet modification in non-obese non-alcoholic fatty liver disease: analysis of biopsies of living liver donors. J Gastroenterol Hepatol. 2012;27:1341-47.

16. Nakamuta M, Morizono S, Soejima Y, Yoshizumi T, Aishima S, Takasugi $\mathrm{S}$, et al. Short-term intensive treatment for donors with hepatic steatosis in living-donor liver transplantation. Transplantation. 2005;80:608-12.

17. El-Meteini M, Dabbous H, Sakr M, Ibrahim A, Fawzy I, Bahaa M, et al. Donor rejection before living donor liver transplantation: causes and cost effective analysis in an egyptian transplant center. Hepat Mon. 2014;14:e13703.

18. Bustelos R, Ayala R, Martinez J, Martin MA, Toledo T, Grande S, et al. Living donor liver transplantation: usefulness of hemostatic and prothrombotic screening in potential donors. Transplant Proc. 2009;41:3791-95

19. Singh MK, Lubezky N, Facciuto M, Contreras-Saldivar A, Wadhera $\mathrm{V}$, Arvelakis A, et al. Upper midline incision for living donor right hepatectomy. Clin Transplant. 2016;30:1010-15.

20. Marubashi S, Nagano H, Wada H, Kobayashi S, Eguchi H, Takeda $\mathrm{Y}$, et al. Donor hepatectomy for living donor liver transplantation: learning steps and surgical outcome. Dig Dis Sci. 2011;56:2482-90. 